\title{
Are Judges Corrupt?an Empirical analysis ofthe Ghana Judiciary.
}

\author{
Awaisu I. Braimah \\ Department of Political Science Education, University of Education, Winneba, Ghana
}

\begin{abstract}
Are judges corrupt? This paper probesthe public perception of endemic corruption within the Ghana judiciary. Theperceived corruption in the judiciary is re-echoed on daily basis by the media,parliamentarians, civil society, court users and lawyers to the effect that court corruption is pervasive at the lower and high courts in Ghana. This paper argue that bribery and corruption have influenced the outcome of many judgements in favour of those with material wherewithal to engage in payoffs and to the detriment of the poor and vulnerable in the Ghanaian society.
\end{abstract}

Keywords: -Bribery, Corruption, Democratic Quality, Judiciary.

\section{INTRODUCTION}

Corruption has been a prominent feature of public institutions since the Graeco-Roman World, yet only relatively recently has it been made the subject of sustained scientific analysis (Lambsdorff, 2007). Many in the ancient World and in modern times, abused their entrusted public offices for private gain and against established customs, norms or laws.Corruption is as old as humanity. Until avarice and ambition cease to be human traits, corruption will continue to flourish (Rotberg, 2009). As a consequence, corruption in modern times continue to be antithetical to sustainable development and also, a retrogressive agent facing developed and peripheral societies. While public or official corruption in the advanced states have been drastically reduced due to constant punishment for those who engage in graft or petty corruption, the phenomenon is still flourishing at an exponential rate in the developing world. This is partly due to politics of patronage and clientele relationships. Corruption is widespread in most African societies (e.g. Angola, Democratic Republic of Congo, Ghana, Nigeria, Tanzania, Zimbabwe, South Africa, Kenyaetc) and has deprived many ordinary citizens for example, from having access to basic necessity of life such as portable water, electricity, housing, education, health facilities, and public places of convenience (i.e. toilet facilities), roads and their like. Nevertheless, contemporary leaders in Africa have vowed to fight corruption root and branch as a result of its suffocating consequences on the economic development of the continent.

The 'war' against corruption in the Ghanaian society has a chequered historical antecedent. Since independence, all attempt to root out corruption in the public and private sphere has been on the agenda of all successive governments - both civilian administrations and military regimes. In the process of combating corruption in the Ghanaian society, many senior civil and public servants, business men and women, former heads of state of Ghana and other members of the general public were punished in one or two of the following: executed or made to pay reparations; the return of illegally acquired state property or sentenced to various jail terms ranging from 10 years and beyond.The object was to weed out corruption in the public and private spheres in Ghana.Yet, corruption in contemporary times continue to recur with impunity in the Ghanaian society. This paper attempt to investigate the veracity or otherwise of the perceived judicial corruption and the level of confidence of the citizenry in the Ghanaian Judiciary. This is necessitated as a result of the dearth of reliable information on the subject matter.

Data and information for this paper was originally collected between 2005 and 2015. Key informants were mainly from lawyers, litigants/court users, court personnel, police and the random sampling of some members of the general public. The sample population size was 200. This source of information was complemented with secondary sources such as books, newspaper publications, journal articles, bulletins from the judicial service, monographs. These sources of information were gleaned and analysed to make sense of the subject matter under discussion.

\section{CONCEPTUAL FRAMEWORK}

The concept "corruption" is an elusive terminology that has been variously defined by various scholars and anti-corruption agencies or organizations. Corruption is seen, first and foremost, as the "utilization of official positions or titles for personal or private gain, either on an individual or collective basis, at the expense of the public good, in violation of established rules and ethical considerations, and through the direct or indirect 
participation of one or more public officials whether they be politicians or bureaucrats. It is an act or acts undertaken with the deliberate intent of deriving or extracting personal and/or private rewards against the interest of the state' (Hope, 1985; 1987; 1997a; Dey, 1989). The Judiciary is a wing of government that is charged with the responsibility of dispensing justice (i.e. irrespective of the social status of an individual or group of individuals, and doing so without fear or favour), and interpreting the constitution in the event of conflict. Judicial corruption includes 'any inappropriate influence on the impartiality of the judicial process by any actor within the court system' (Hossain, 2007). Transparency International (2006) defines corruption as 'the abuse of entrusted power for private gain'. The 'private gain' besides the usual material acquisition, may also include sex for justice as a court male official was caught on camera having sex with a defendant in the recent exposure of some judges and court personnel in Ghana. Corruption manifests in acts such as fraud, conflict of interest, embezzlement of funds, receiving and paying bribes, corporate malfeasance, nepotism and/or granting favours or privileges to friends and their like. These definitions of corruption suffice for the purposes of conceptualization. However, the most common definition of the concept of "corruption" is that of RoseAckerman who recognizes the inadequacies inherent in the discourse of defining corruption. As clearly captured by Rose-Ackerman (2004): 'Corruption' is a term whose meaning shifts with the speaker. ... I use the common definition of corruption as the "misuse of public power for private or public gain," recognising that "misuse" must be defined in terms of some standard. Many corrupt activities under this definition are illegal in most countries - for example, paying and receiving bribes, fraud, embezzlement, self-dealing, conflicts of interest, and providing a quid pro quo in return for campaign gifts. However, part of the policy debate turns on where to draw the legal line and how to control borderline phenomena, such as conflicts of interest, which many political systems fail toregulate. Judicial corruption is defined as ... the 'use of public authority for the private benefit of court personnel ... (Buscaglia, 2001). This phenomenon is incongruous to court procedures. Marselli and Vannini, 1997; Acemoglu and Verdier, 2000; argue that official and/or institutional corruption is a major catalyst for the growth of organized criminal gangs such as terrorists, human trafficking, the use and circulation of narcotic drugs, nuclear, chemical and biological materials, money laundering and low economic growth.. All these pose a serious threat to global peace and security as well as socio-political stability of states ingrained in institutional corruption (e.g., court corruption) in whatever form. In Ghana, drug barons are usually granted bail by Judges in bizarre circumstances and against the law - trafficking in narcotic drugs is a non-bail offence in Ghana.

Scholars on judicial corruption or malfeasance in public life (Buscaglia, 2001; Langseth and Stolpe, 2001; Heidenheimer, 2002) meld the concept of "corruption" intotwo main categories: petty or administrative corruption and operational or grandcorruption. Petty corruption is a routine occurrence involving court officials extorting material resources from court users for personal benefit. It includes charging illegal fees to either locate or dislocate files to expedite or delay in the hearing of cases. Grand corruption involves politicallymotivated court rulings and/or undue changes of venue where judges stand to gain economically or career advancement as a consequent of their corrupt practices (Buscaglia, 2001). The former is the thrust of this paper even though the two categories (petty or administration corruption and grand corruption) exists side by side in the Ghanaian society

The various definitions of the concept of "corruption" by various scholars although differ in wording, they are essentially the same in meaning. Corruption in whatever form it manifests in any society, is considered undesirable. Judicial corruption is particularly distasteful as a result of the discretional powers of a judge to order for the execution of individuals or group found guilty on charges levelled against them (depending on the gravity of the offence such as treason, murder, espionage etc), imprison or remand in prison custody. Hence, judges have the unique powers to curtail the freedom of any individual. In Ghana, the judiciary is referred to as 'second to God' on the planet. This is as a result of the immense powersjudges' wield. Society therefore bemoan court corruption as the "innocent" could be incarcerated for their inability to engage in payoffs. In the same vein, "defendants" who are capable of engaging in payoffs will always have their way. This, in no small way has the potential to derail citizens' confidence in the judicial system.

\section{JUDICIAL CORRUPTION FROM PERCEPTIONTO REALITY}

Exposing judicialcorruption in concrete terms has been a difficult terrain. As a result, judicial corruption has been a perception - since independence - in spite of the consistency in surveys, narratives from court users, prosecutors, legal counsels and the general public at large, that court corruption is endemic in the Ghanaian judiciary.The court is an avenue where concrete evidence is/are required before a judge or judges could make informed ruling on cases. And since bribery and corruption are undertaken in secrecy, it is therefore difficult, if not impossible for people who alleges court corruption of court personnel and judges to expose such acts in the law court beyond reasonable doubt. It was therefore intriguing that an undercover journalist (by name AnasAmeriyawAnas) and his Tiger Eye PI organization to expose bribery and corruption within the rank of the 
judiciary in such a magnitude scale caught on camera. Ghanaians having watched the video on September 22 , 2015 depicting how lower and high court judges as well as Judicial Service staff received various sums of money or payoffs including livestock to influence the outcome of cases pending before them to favour defendants; came to the conclusion that the wide held suspicion of court corruption by the general public within the ranks of the judiciary is now a reality and not a perception.

\section{Effects of the Judicial Scandal}

The swift actions by the President of the Republic of Ghana (His. Excellency, John DramaniMahama) and the Chief Justice (Georgina Theodora Wood) as well as the Judicial Council in investigating the scandal is worth commending. The Tiger Eye PI first petitioned the President of Ghana, who without shielding the petition, referred the matter to the Chief Justice for further investigations to either confirm the rot in the judiciary as presented by the Tiger Eye PI or absolve those implicated as natural justice demand. The Chief Justice and the Judicial Council put together a five-member investigation committee to look into the petition by given opportunity to those implicated in the scandal to defend themselves. In spite of the various interlocutory injunctions filed by some of the implicated lower and high court judges to stop the investigating committee from commencing work, the committee nevertheless, went on with its investigations by inviting the accused persons to appear before it. After several weeks of work, the investigating committee found the defendants guilty of the offence. The work of the five member investigative body led to the summary dismissals of some lower and high court judges implicated in the scandal. The tablepreceding, shows the summary of the lower and high court judges who have been sacked with or without benefits.

Table 1: Dismissed Judges without Benefits

\begin{tabular}{|c|c|c|c|c|}
\hline $\mathbf{S} / \mathbf{N}$ & Name of Judge & Designation & City/Town & Nature of Punishment \\
\hline 1. & $\begin{array}{l}\text { Benjamen } \quad \mathrm{Y} . \\
\text { Osei }\end{array}$ & $\begin{array}{l}\text { Circuit court } \\
\text { Judge }\end{array}$ & Juaben & $\begin{array}{l}\text { Accused Judge did not } \\
\text { show remorse and was } \\
\text { therefore dismissed } \\
\text { without benefits for "stated } \\
\text { misbehaviour under article } \\
\text { 151(1) of the } 1992 \\
\text { Constitution. }\end{array}$ \\
\hline 2. & $\begin{array}{l}\text { Frank Kingsley } \\
\text { Oppong }\end{array}$ & $\begin{array}{l}\text { District } \\
\text { Court }\end{array}$ & Kasoa & $\begin{array}{l}\text { Removed from office } \\
\text { without benefits }\end{array}$ \\
\hline 3. & $\begin{array}{l}\text { Alfred K. A. } \\
\text { Mensah }\end{array}$ & $\begin{array}{l}\text { District } \\
\text { Court }\end{array}$ & Somanya & $\begin{array}{l}\text { Removed from office } \\
\text { without benefits }\end{array}$ \\
\hline 4. & $\begin{array}{ll}\text { Alex } & \text { Obeng } \\
\text { Asante } & \\
\end{array}$ & $\begin{array}{l}\text { Circuit } \\
\text { Court }\end{array}$ & Tarkwa & Applicable \\
\hline 5. & $\begin{array}{l}\text { Emmanuel K. } \\
\text { Sunu }\end{array}$ & $\begin{array}{l}\text { Circuit } \\
\text { Court }\end{array}$ & Bolgatanga & Applicable \\
\hline 6. & $\begin{array}{l}\text { Baptist } \\
\text { KwadwoFilson }\end{array}$ & $\begin{array}{l}\text { Circuit } \\
\text { Court }\end{array}$ & Bibiani & Applicable \\
\hline 7. & $\begin{array}{l}\text { Emmanuel } \\
\text { Opare }\end{array}$ & $\begin{array}{l}\text { Circuit } \\
\text { Court }\end{array}$ & Techiman & Applicable \\
\hline 8. & $\begin{array}{l}\text { Florence } \\
\text { OtooNinepence }\end{array}$ & $\begin{array}{l}\text { Circuit } \\
\text { Court }\end{array}$ & Tema & Applicable \\
\hline 9. & $\begin{array}{ll}\text { Isaac } & \text { B. } \\
\text { Akwantey } & \end{array}$ & $\begin{array}{l}\text { Circuit } \\
\text { Court }\end{array}$ & $\mathrm{Wa}$ & Applicable \\
\hline 10. & Samuel Ahiabor & $\begin{array}{l}\text { Circuit } \\
\text { Court }\end{array}$ & Adidome & Applicable \\
\hline 11. & William Baffoe & $\begin{array}{l}\text { Circuit } \\
\text { Court }\end{array}$ & Cape Coast & Applicable \\
\hline 12. & $\begin{array}{l}\text { Michael } \\
\text { BoamahGyamfi }\end{array}$ & $\begin{array}{l}\text { District } \\
\text { Court }\end{array}$ & Mampongten & $\begin{array}{l}\text { Removed from office } \\
\text { without benefits }\end{array}$ \\
\hline 13. & $\begin{array}{l}\text { Jacob } \\
\text { Amponsah }\end{array}$ & $\begin{array}{l}\text { District } \\
\text { Court }\end{array}$ & Ejisu & $\begin{array}{l}\text { Removed from office } \\
\text { without benefits }\end{array}$ \\
\hline 14. & $\begin{array}{ll}\text { Samuel } & \text { Essel } \\
\text { Walker } & \end{array}$ & $\begin{array}{l}\text { District } \\
\text { Court }\end{array}$ & Bolgatanga & $\begin{array}{l}\text { This Judge was not } \\
\text { dismissed as a result of } \\
\text { inadequate } \\
\text { findings against him. He }\end{array}$ \\
\hline
\end{tabular}




\begin{tabular}{|c|l|l|l|l|}
\hline & & & & $\begin{array}{l}\text { was therefore reprimanded } \\
\text { in a written letter to be of } \\
\text { good behaviour. }\end{array}$ \\
\hline 15. & $\begin{array}{l}\text { Kaakyire Atta } \\
\text { Owusu }\end{array}$ & $\begin{array}{l}\text { Circuit } \\
\text { Court }\end{array}$ & $\begin{array}{l}\text { Town/City not } \\
\text { disclosed by } \\
\text { the Judicial } \\
\text { Secretary }\end{array}$ & $\begin{array}{l}\text { Removed from office } \\
\text { without benefits }\end{array}$ \\
\hline 16. & Isaac Amoah & $\begin{array}{l}\text { Circuit } \\
\text { Court }\end{array}$ & Applicable & $\begin{array}{l}\text { Removed from office } \\
\text { without benefits }\end{array}$ \\
\hline 17. & Stephen Azure & $\begin{array}{l}\text { Circuit } \\
\text { Court }\end{array}$ & Applicable & $\begin{array}{l}\text { Removed from office } \\
\text { without benefits }\end{array}$ \\
\hline
\end{tabular}

Table 2: Dismissed Judges with Benefits

\begin{tabular}{|c|c|c|c|c|}
\hline $\mathbf{S} / \mathbf{N}$ & Name of Judge & Designation & City/Town & Punishment/Reason(s) \\
\hline 1. & SeyramTsatsuAzumah & $\begin{array}{l}\text { Circuit } \\
\text { Court Judge }\end{array}$ & Akropong & $\begin{array}{l}\text { These category of } \\
\text { Judges were remorseful } \\
\text { and apologised to } \\
\text { Ghanaians and the } \\
\text { Judiciary for bringing } \\
\text { the name of the } \\
\text { institution into } \\
\text { disrepute. They were } \\
\text { therefore removed } \\
\text { from office with } \\
\text { benefits. }\end{array}$ \\
\hline 2. & Paul K. Alhassan & $\begin{array}{l}\text { District } \\
\text { Court }\end{array}$ & $\begin{array}{l}\text { Agona } \\
\text { Ashanti } \\
\text { District } \\
\text { Court }\end{array}$ & $\checkmark$ \\
\hline 3. & Albert Zoogah & $\begin{array}{l}\text { District } \\
\text { Court }\end{array}$ & Ashaiman & $\checkmark$ \\
\hline 4. & Courage OforiAfriyie & $\begin{array}{l}\text { District } \\
\text { Court }\end{array}$ & Offinso & $\bar{\checkmark}$ \\
\hline
\end{tabular}

Source: Author's compilation of Judicial Council's press releases

Besides the lower court judges' saga, some high court judges were also implicated in the court corruption. Seven high court judges were suspended having found a prima faciecase against them by the fivemember investigation committee - those under suspension have all allowances revoked except rent and are expected to receive half of their salary until the finality of the case is determined. Two of the high court judges have filed numerous interlocutory injunctions against the process to investigate them. Proceedings to determine a prima facie case against one of the Justices has been suspended on grounds of ill-health. Two of the suspended judges have been removed from office by the President of the republic acting on the advice of the Judicial Council. The summary of the statuses of the high court judges indicted in the judicial scandal are captured hereunder.

Table 3:Status of High Court Judges Implicated in the Judicial Scandal

\begin{tabular}{|l|l|l|l|}
\hline S/N & \multicolumn{1}{|c|}{ Name } & \multicolumn{1}{c|}{ Designation } & \multicolumn{1}{c|}{ Status of Case } \\
\hline 1. & $\begin{array}{l}\text { Justice Francis } \\
\text { K. Poku }\end{array}$ & $\begin{array}{l}\text { High Court } \\
\text { Judge }\end{array}$ & Suspended \\
\hline 2. & $\begin{array}{l}\text { Justice Kofi } \\
\text { Essel Mensah }\end{array}$ & $\begin{array}{l}\text { High Court } \\
\text { Judge }\end{array}$ & Suspended \\
\hline 3. & $\begin{array}{l}\text { Justice John } \\
\text { AjetNasam }\end{array}$ & $\begin{array}{l}\text { High Court } \\
\text { Judge }\end{array}$ & $\begin{array}{l}\text { Removed from office in accordance } \\
\text { with Article 146 of Ghana's 1992 } \\
\text { Constitution. }\end{array}$ \\
\hline 4. & $\begin{array}{l}\text { Justice Ernest } \\
\text { Obimpeh }\end{array}$ & $\begin{array}{l}\text { High Court } \\
\text { Judge }\end{array}$ & $\begin{array}{l}\text { Removed from office in accordance } \\
\text { with Article 146 of Ghana's 1992 } \\
\text { Constitution. }\end{array}$ \\
\hline
\end{tabular}




\begin{tabular}{|l|l|l|l|}
\hline 5. & $\begin{array}{l}\text { Justice Kwame } \\
\text { OheneEssel }\end{array}$ & $\begin{array}{l}\text { High Court } \\
\text { Judge }\end{array}$ & Suspended \\
\hline 6. & $\begin{array}{l}\text { Justice Ivy } \\
\text { Heward Mills }\end{array}$ & $\begin{array}{l}\text { High Court } \\
\text { Judge }\end{array}$ & Suspended \\
\hline 7. & $\begin{array}{l}\text { Justice Gilbert } \\
\text { AyisiAddo }\end{array}$ & $\begin{array}{l}\text { High Court } \\
\text { Judge }\end{array}$ & Suspended \\
\hline 8 & $\begin{array}{l}\text { Justice Charles } \\
\text { Quist }\end{array}$ & $\begin{array}{l}\text { High Court } \\
\text { Judge }\end{array}$ & $\begin{array}{l}\text { Proceedings suspended on } \\
\text { grounds of ill-health }\end{array}$ \\
\hline 9. & $\begin{array}{l}\text { Justice } \\
\text { Mustapha } \\
\text { Logoh }\end{array}$ & $\begin{array}{l}\text { High Court } \\
\text { Judge }\end{array}$ & $\begin{array}{l}\text { Judge instituted legal action against the } \\
\text { Chief Justice and Tiger Eye PI which is } \\
\text { still pending in court. }\end{array}$ \\
\hline 10. & $\begin{array}{l}\text { Justice Paul } \\
\text { UuterDery }\end{array}$ & $\begin{array}{l}\text { High Court } \\
\text { Judge }\end{array}$ & $\begin{array}{l}\text { Judge instituted legal action against the } \\
\text { Chief Justice and Tiger Eye PI which is } \\
\text { still pending in court }\end{array}$ \\
\hline \multicolumn{2}{|l|}{ Source: Press Release of the Judicial Council and Daily Graphic, October 6 2015 issue }
\end{tabular}

Another effect of the court corruption that rocked the Ghana judiciary is the summary dismissal of nineteen senior administrative staff including a court registrar. The effect of these disciplinary action it is expected, will minimize the bare-faced court corruption to the minimum. It is also an opportunity for the Chief Justice and the Judicial Council of Ghana to pause, reflect and carry out some reforms to curtail the incidences of court corruption among judges and administrative personnel in general. This will in one way or another, regain some public confidence in the judiciary and to prevent a possible teetering of the Ghana Judiciary on the edge of collapse. In the view of this paper, the exposure of the judicial rot by the investigative journalist AnasAmeriyawAnas - is good for the total overhaul of the justice system to better serve the needs of court users - people of all walks of life regardless of their financial statuses, ethnic, religious or political affiliation. The mid-boggling question that still need further interrogation is: Why will a judge accept bribe or material resource to pervert justice? Or what is the motivation behind a judge desecrating the bench by indulging in corrupt schemes?

\section{MAJOR INFLUENCES OF JUDICIAL CORRUPTION IN GHANA}

The ideal judicial system in liberal societies as in Ghana, have the powers to determine whether the fundamental rights of citizens, regardless of their background, have been infringed upon by the state and its surrogates or the powerful oligarchies in societies. The judicial system also has the responsibility to interpret laws to resolve disputes emanating from any quarter - whether from the executive, the legislature or any public or private institutions - for public good. It is therefore mind-boggling to comprehend why some elements in the judicial system will surrender these responsibilities (to ensure the protection of individual rights and thepublic good) for personal material and financial gains. Court corruption flouts the rules of engagement and give an urge to a cross section of influential individuals over others (the beneficiaries being the affluent in society and the poor and vulnerable at the receiving end of discrimination). The major influences or causes of judicial corruption identified in this paper included the following: First, judicial corruption is a replica of what exists in the wider domain of society. Ghana, since 1992, the political leadership and other senior public officials closely associated with government over the years, have not exhibited exemplary stewardship in the management of state resources. For example, the Auditor-General's annual report to the legislative arm of government has exposed and is still exposing graft and grand looting of state resources by ministers of state and senior public officials or bureaucrats for the past twenty-four years. Yet, no one has been prosecuted or directed to refund misappropriated state funds. Hardly any day passes without reported cases in the mass media of crass corruption and/or embezzlement of state funds by the top echelon of political leadership and their surrogates. Many of those implicated or reported in the news media and in the Auditor-General's report are walking free with arrogance. A few of the cases involving political leadership and senior bureaucrats that found their way to the law courts never ended conclusively or are won in bizarre circumstances. The surge of corruption in the public and private spheres seemed to be as a result of the incredible failure of political leadership to stem the haemorrhaging support to the language of pervasive corruption that has spread across the Ghanaian society. The absence of exemplary ethical political leadership over the years, clearly shows that, personal aggrandizement or private interests override national interests and/or public good. It is therefore not surprising that an important arm of government - i.e. the Judiciary - will also join the fray of bribery and corruption and reducing justice for those with resources to engage in payoffs to have their way. The other segment of society - the have-nots - who are unable to engage in payoffs for justice, may forever endure the pain of haemorrhage injustice. 
Second, the wide and uncontrolled discretional powers given to judges tend to be the magnetic impulse for judicial corruptionand the abuse of the fundamental rights of citizens in Ghana. There are many 'innocent' Ghanaianswho are incarcerated and languishing in various jails across the country owing to the reckless discretional powers exercised by judges. For example, cases involving the poor or the less influential in society and the affluent that include the political class, captain(s) of industry and church leaders for instance, who are able to pay illicit payoffs to judges always have their way out. It is not uncommon in Ghana to hear a court sentenced some 'poor' individual(s) to serve prison terms ranging from three to ten years in hard labour for stealing a basket of tomatoes, plantain, goat or a fowl. However, the political class and other influential individuals in society involved in crass corruption against the state are given prison sentences ranging from two to four years. Even in those instances, those convicted and sentenced are usually granted Presidential pardons having served a year or two.Accordingly, many less influential people are found in the various prisons whose lives have been blighted by the sense of the misuse ofdiscretional powers by judges, and the hopelessness common to those who are at the mercy of the whims and caprices of alleged corrupt judges. A good law must be equitable and transparent in its application to give confidence to all and sundry - rich, influential and the poor.

Besides, the judicial immunity granted judges have been truly misinterpreted by some judges as being above the due process of law. This is evident in the numerous interlocutory injunctions being sought by some of the accused high and lower court judges against the Chief Justice's investigative committee. The accused judges or justices argue that the judicial immunity granted them by the constitution is being flouted by the Judicial Council. It is altruistic that judicial immunity granted judges in various constitutions are meant to be the bulwark of justice, and to re-affirm the independence of the judiciary. The immunity is supposed to 'toughen 'judges to dispense justice without an iota of fear or favour. However, some judges in Ghana are hiding behind judicial immunity to pervert justice in favour of court users who are involved in payoffs. This unethical behaviour by some judges to a large extent, have immensely dented the image of the judiciary as an institution soaked in corruption; and threatens to ruin the core foundation of the Ghana judiciary. While this paper is not in the business to sermonize about right and wrong, it is a fact that judicial immunity granted judges cannot be absolute in the face of due process of law. Furthermore, the monitoring framework of the lower and high court judges over the years appeared to be weak in Ghana. As a consequence, judges have controversially delivered judgements/rulings that defies basic logic of law in high profile cases involving politicians and other well to do members of society. Judicial corruption benefits only individual judges, prosecutors, court personnel, and the police for example. Yet the state suffer the consequences (e.g. corruption impedes economic development, undermine the stability of states, lower economic growth and encourages despondency among citizens).If judgements or rulings that are delivered by judges on daily basis were seriously scrutinized or monitored by the Judicial Council, many of the controversial judgements that usually attract public outcry would have been avoided or minimized. Since there is a dysfunctional monitoring of judges by the Judicial Council, corruption and other abusive or lackadaisical practices are bound to happen. Admittedly, corruption is secretive by nature and the ability to expose corrupt practices at the lower and high courts is a difficult task. But, it is possible for the Judicial Council of Ghana to assess controversial judgements/rulings delivered by judges that defies the rubrics of law or incongruous to procedural rules. In spite of the existence of appellate courts for aggrieved litigants and court users to appeal against lower and high court rulings, the poor financial wherewithal of most court users did not give room for such rulings to be re-examined at the Appeals court. Hence, the poor in society are the hardest hit of judicial or court corruption. Another influence of court corruption is rooted in the Ghanaian culture itself. There is hardly any distinction between a gift and a bribe in Ghana. Traditional authorities (e.g. chiefs and queen mothers) are showered with gifts ranging from foodstuffs, livestock and money as part of paying homage to maintain custom and tradition. This gesture is extended to public office holders and their surrogates. Gifts are usually given to very influential individuals in society before and during festivities (e.g. during Christmas, Muslim festivities, local festivals etc.) and other special occasions. Usually, these gifts are given to judges, the clergy, ministers of state, and opinion leaders in various societies, teachers, traders, industry players and other high ranking members of society without any prior arrangements or strings of conditions. In the Ghanaian tradition or culture, gifts under normal circumstances are not to be rejected. Thejudges are part of the wider society and its traditions and customs. These societal norms predispose judges' prosecutors, police and court personnel to the vulnerability of bribery and corruption. There is hardly any distinction between acceptable gifts and the unacceptable ones. But in the case of the recent judicial scandal involving some high and lower court judges, the 'gifts' were clearly acts of bribery and corruption. For, the 'gifts' were given to the judges with an object to influence cases before them - 'gifts' they readily accepted and freed or granted bail to the defendants charged with the possession of narcotic drugs, grand corruption and rape cases. In Ghana, cases involving narcotic drugs are non-bail offences. However, some judges in a bizarre circumstance, have granted bail to drug barons in spite of criticisms from Ghana Narcotic Control Authority, Civil Society Organizations (CSOs) and the general public. In spite of the seemingly high compensation or salaries and other allowances paid to judges in comparative terms - they are part of Article 71 office holders whose emoluments or conditions 
of service are better than those outside the Article 71 bracket - their compensation package is still not enough if compared to their counterparts in neighbouring states in Africa. This paper is not in any way justifying judicial corruption or encouraging judges to use their low compensation as an alibi to engage in illicit practices. The state of Ghana need to do more by reviewing further the existing allowances and other emoluments to judges as a first step toward sanitizing the judicial system and/or minimizing court corruption.

\section{IMPLICATIONS OF JUDICIALCORRUPTION ON THE GHANAIAN ECONOMY}

The recent expose of corruptible activities in the rank of the judiciary by the Tiger Eye PI has damning implication/consequences of the democratic credentials of Ghana. Democracy without an independent judiciary is tantamount to being in a state of nature asespoused by Thomas Hobbesor in a chaotic autocratic regime trampling on the rights of the citizenry. In such a phenomenon, it is rulers who rule without governing. The judicial corruption scandal did not only hit the judiciary as an arm of government, but it has shaken the core foundation of the state because of the following implications: Politically, democracy entailsa webof civil, political, social and economic rights of the citizenry. For instance, democratic rights of the individual and groups in a democracy include: freedom of speech and of the press, security against arbitrary arrest and imprisonment, freedom of association, the right to assembly, freedom of movement, the right to fair hearing and representation, and freedom of religion among others. "As a corollary, democracy is held to require the establishment of an independent judiciary and courts to which everyone can have access(Bullock \&Trombley, 1999). As aptly captured by the Chair of Transparency International: Equal treatment before the law is a pillar of democratic societies. When courts are corrupted by greed or political expediency, the scales of justice are tipped, and ordinary people suffer. Judicial corruption means the voice of the innocent goes unheard, while the guilty acts with impunity (Labelle, 2007).

In this perspective, the effective functioning of the Judiciary is crucial in the sustenance of democracy and the maintenance of a stable political climate (Ambrose, 1995:91). Sustainable democracy thesis suggest that 'serious corruption makes political systems less democratic' (cited in Johnston, 1997). The judiciary and the courts are supposed to, not only to protect these rights, but also, act impartially in discharging and upholding the substance of the law with integrity - irrespective of the parties involved - when passing judgements. The democratic maturity chalked by Ghana could be endangered if the citizens, political parties, and other associations perceives the judiciary to be corrupt. The legal mistrust toward the judiciary may result to individuals, groups and institutions taking the law into their own hands. This scenario has the propensity to derail the democratic credentials of Ghana as the beacon of democracy in Africa.

Economically, corrupt judicial systemscares foreign and local investors from investing their capital or resources in a country. Foreign investors around the world will customarily, survey the effectiveness, efficacy, application and the certainty or otherwise of a country's judicial system or laws to satisfy themselves that, they are likely to have a fair hearing in the event of a conflict or legal tussle between the foreign investor(s) and the host state or between the investors and non-state actors. In the words of Smith (1978), in his Lectures onJurisprudence that a factor that "greatly retarded commerce was the imperfection of the law and the uncertainty in its application ..." (Smith, 1978:528). Again, and as aptly captured by Buscaglia (1997), "Judicial Corruption hampers economic development by undermining the stability and predictability in the interpretation and enforcement of the law" (Buscaglia, 1997).According to Elliott, corruption compromises the efficacy and efficiency of economic activity ... and also, contort and distort public perceptions of how - and how well -a proper market economy works (Elliott, 1997). Judicial corruption is an impediment to the political and economic development of most developing countries and the court rooms remain slightly spooky to many entrepreneurs. In a country where court corruption exists, 'entrepreneurs are aware that some of the proceeds from their future investments may be claimed from corrupt officials' in the event of a legal tussle involving their businesses (Mauro, 1997). This uncertainty lower investments and deprive the country sustainable economic development.

Socially, judicial corruption in a country reflects widespread corruption in society. A corrupted society breeds corrupt individuals and the reverse is the case in all facets of public and privatelife. Judges pay more attention to family ties in law as against the fact of law. As stated: 'corrupt judges who support the interests of their relatives overlooks the notion that it may be more dishonourable for a judge to ignore the wishes of a family member than to abide strictly by the law. Nor is the rule of law as important ... as individual relationships' (Pepys, 2007). This presupposes that court users who lacked social connectivity with judges or the power that be are usually treated with disdain and contempt. Court corruption creates inequality between the haves and the have-nots. This provides a fertile breeding ground for petty corruption, which in turn, leads to further inequalities in the accessibility of the judicial system (Uslaner, 2008). 


\section{DISCUSSION OF FINDINGS}

The findings in this paper seem to lend credence to the already wide spectrum suspicion by the public that the judiciary is corrupt. The responses from some court users, lawyers and the Ghanaian public reflected and deepen the existing perception that the judiciary is corrupt (respondents were drawn based on their interaction with the courts and who have either paid some form of bribe to court personnel, judges and the police or lost cases as a consequence of their inability to pay bribes). However, the fact that some court personnel, judges and the police are ingrained in acts of court corruption, does not jell logically to brand the entire judicial system of Ghana as corrupt. Unfortunately, public opinion heavily favoured the branding of whole judiciary as a corrupt arm of government in governance. For instance, $60 \%$ of the participant thought that court corruption was the main reason for their lack of confidence and the visceral hate for the Ghanaian justice system, whilst $2 \%$ of prosecutors and $15 \%$ of court personnel stating that they knew of bribes paid to some judges and court personnel to expedite action on cases in favour of defendants. $4 \%$ of police personnel indicated that they knew of enormous pressure from politicians, chiefs and opinion leaders on the police and judges to pervert justice on cases before them. According to the police respondents, these category of influential individuals then turn to accuse the police of inaction and extortion. As observed by Pepys, 'one influence that can lead judges to make decisions based on factors other than the facts and applicable law is fear of retribution by political leaders, appellate judges, powerful individuals, the public and the media' (Pepys, 2007). A notable finding of this paper is in the view of some participants $(30 \%)$ that reporting cases to the police and pursuing cases in court is never an option they will consider now and the future. According to them, beside the fact that they cannot hire or pay for the services of legal counsels, they have no confidence of ever going to get justice in court proceedings - the rich and the most influential people in society will use their affluence to influence ruling from the court in their favour. As a result, they prefer to report cases to family heads of offenders to turning to the police and the courts. In situations where family heads of offenders are not known, victims prefer to ignore the case and bear the pain therein.

\section{RECOMMENDATIONS ANDCONCLUSION}

The discussions above indicate the pervasiveness of corruption in the Ghanaian society. A corrupt society produces corrupt individuals. The alleged corruption in the Judiciary is a drawback to the democratic quality of Ghana. However, it will be a converse accident or preposterous to brand the entire judiciary as corrupt. Certainly, there is a plethora of men and women of integrity serving on the bench. Indeed, the expose of Tiger Eye PI identified a number of judges who could not be influenced by material gain or benefit in any way to pervert justice. Such judges also warned the individuals of prosecution and incarceration if they dare attempt to bribe them to influence the judgements on cases before them. This gives some hope and assurance to the ordinary Ghanaian that the entire judiciary system is not corrupt. It is in the light of this phenomenon that this paper recommends the following steps as a way of damage control and repair of the judiciary arm of government from the brink of total mistrust from the general public.

First, the Chief Justice and the Judicial Council of Ghana must carry out judicial reforms at the lower and high courts to ensure credibility of those serving on the bench. In this perspective, the recruitment process to the bench must consider intensifying or improving the background check of would-be judges before they are recruited to serve on the bench. The background check may include family history, school records of would-be judges must be thoroughly interrogated and finally, the peers (either school peers or community peers) of the would-be judges must be consulted for confidential reports. These processes though laborious, may assist the Judicial Council in making informed decision on the choice of judges to serve on the bench. This will minimize the possibility of recruiting questionable characters into the ranks of the judiciary.

Second, the swift investigations instituted by the Chief Justice (CJ) and the Judicial Council (JC) since the outbreak of the judicial scandal need commendation. This has already sent strong signal to the general populace that the top hierarchy of the judiciary arm of government had no intention to connive, condone and shield any of its member involved in any scandalous action or inaction in direct contravention of the laid down rules of the bench. The empirical evidence as captured on the tape and camera - i.e. judges were seen receiving various sums of money, yams and goats with the sole aim to influence the outcome of judgements of cases pending before them - and premiered by the Tiger Eye PI to the general public, is so incontrovertible for persons captured on the tape to extricate themselves from the bribery allegations levelled against them. It is therefore gratifying that the Chief Justice and the Judicial Council are following due process of law to give a window of opportunity for the accused judges to be heard. Judges who are found culpable to the various charges levelled against them, must face the rigours of the law not only to serve as a deterrent to others on the bench, but as one of the effective ways to repair the sunken image of the judiciary in the sight of the general public.

To further build the confidence of the citizenry in the judiciary, controversial and/or weird judgements that emanates from the lower and high courts must henceforth be monitored by the superior courts to ensure that such judgements are rooted in law. In other words, discretionary powers or judgements from the lower and the 
high courts must be reviewed (where necessary) if such discretional judgements defy basic logic of law and also, injurious to individuals, groups and society as a whole. This will enable judges to be guided by law in passing judgements other than any other consideration in justice delivery.

In conclusion, corruption is pervasive and seem institutionalized in public life in the Ghanaian society. Tackling corruption implies employing multifaceted approach in dealing with the canker that has eaten deep into the Ghanaian social fabric. In doing so, there is the need to cast the net widerby implementing and empowering the arsenal of the proposed National Anti-Corruption Plan (NACAP) - NACAP has been on the drawing board for decades and governments come and go without implementing it - and other agencies to function effectively and efficiently. Accordingly, the fight against corruption must not be limited only to the judiciary, but must also include civil and public servants, institutions and agencies to root out corruption within the ranks of all Ministries, Departments and Agencies (MDAs). The works of Tiger Eye PI have already exposed high profile corruption in some departments and agencies of the state. These included the wanton diversion of state resources into individual pockets and connivance by officials of the Customs, Excise and Preventive Service (CEPS) of the Ghana Revenue Authority (GRA) with importers to undervalue or under declare goods and thereby denying the state the 'badly' needed resources for economic and social development; the Driver and Vehicle License Authority (DVLA) and the smuggling of Ghana's cocoa beans to neighbouring states through the active connivance of security personnel mandated to monitor and fight against smuggling at Ghana's borders. Some of these officials caught on tape receiving bribes were prosecuted at the various law courts of Ghana. The appointments of some the officials caught on tape sabotaging the state were terminated. Hence, the attempt by some of the accused judges and magistrates to frustrate or prevent the investigation team put together by the Chief Justice and the Judicial Council through interlocutory injunctions further proves that people have questions to answer. Ironically, some of the accused judges presided over cases of corruption of some public and civil servants exposed by the Tiger Eye PI and were sentenced accordingly to various jail terms. What makes this latest exposure illegal? What is good for the goose, is also good for the gander.

\section{REFERENCES}

[1] Acemoglu, D. and Thierry Verdier (2000). "The Choice between Market Failures and Corruption". The American Economic Review, Vol. 90. No. 1, pp 194-211

[2] Ambrose, B. P, (1995).Democratization and the Protection of Human Rights in Africa: Problems and Prospects. Greenwood Publishing Group.

[3] Arat, Zehra F. (1991), Democracy and Human Rights in Developing Countries. Boulder; Colo: Lynne Reinner Publishers.

[4] Bullock, A. and Trombley, S. eds. (1999). The Northern Dictionary of Modern Thought. NewYork: W. W. Norton \& Company:

[5] Buscaglia, E. (1997). 'Corruption and Judicial Reform in Latin America. Policy Studies Journal Vol. 17 No, 4.

[6] Buscaglia, E. (2001). "An Economic and Jurimetrics Analysis of Official Corruption in the Courts". United Nations Office for Drug Control and Crime Protection. Vienna: Centre for International Crime Prevention.

[7] Daily Graphic (October 6, 2015).'7 High Court Judges Suspended'. Issued No. 198990. Accra

[8] Dey, H. K. (1989). 'The Genesis and Spread of Economic Corruption: aMicrotheoreticInterpretation'. World Development 17(4): 503 - 511

[9] Elliott, K. N. ed. (1997). Corruption and the Global Economy. Washington D, C.: Institute for International Economics.

[10] Heidenheimer, A. (2002). "Perspectives on the Perception of Corruption." In Arnold Heidenheimer and Michael Johnston (eds.). Political Corruption, $3^{\text {rd }}$ ed. New Brunswick, NJ: Transaction.

[11] Hope, K. R. Snr. (1985). 'Politics, Bureaucratic Corruption, and Maladministration in the Third World'. International Review of Administrative Sciences 51(1): 1 - 6.

[12] Hope, K. R. Snr. (1987). 'Administration Corruption and Administrative Reforms in Developing States'. Corruption and Reform 2(2): $127-147$.

[13] Hope, K. R. Snr. (1997a). African Political Economy: Contemporary Issues in Development. rmonk, NY: M. E. Sharpe

[14] Hossain, K. (2007). "Executive Summary: key judicial corruption problems", in Global Corruption Report 2007: Corruption in Judicial Systems. Transparency International: Cambridge University Press.

[15] Johnston, M. (1997). "Public Officials, Private Interests, and Sustainable Democracy: When Corruption and Politics Meet", in Kimberly Ann Elliot (Ed.). Corruption and theGlobal Economy. Washington D. C.: Institute For International Economics. 
[16] Lambsdorff, J. G. (2007). The Institutional Economics of Corruption and Reform: Theory, Evidence and Policy. Cambridge University Press

[17] Langseth, P. and Oliver Stolpe (2001). "Strengthen the Judiciary Against Corruption”. International Year Book for Judges. Australia.

[18] Leiken, R. S. (1996). "Controlling the Global Corruption Epidemic”. Foreign Affairs, pp 55-73.

[19] Maselli, R. and Marco Vannini (1997). "Estimating a Crime Equation in the Presence of Organized Crime: Evidenced from Italy". International Review of Law and Economics, $\quad$ Vol. 17. No. 1: pp89113

[20] Mauro, P. (1995). “Corruption and Growth”. Quarterly Journal of Economics, 110: pp 681-711

[21] Mauro, P. (1997). "The Effects of Corruption on Growth, Investment, and Government Expenditure: A Cross-Country Analysis", in Kimberly Ann Elliot (Ed.), Corruption and the GlobalEconomy. Washington D. C.: Institute of For International Economics

[22] Pepys, M. N. (2007). "Corruption within the judiciary: causes and remedies”, in Global Corruption Report 2007. Transparency International Excerpt: Cambridge University Press.

[23] Rose-Ackerman, S. (1978). Corruption: A Study in Political Economy. New York: Press

[24] Rotberg, R. I. Ed. (2009). Corruption, Global Security, and World Order. World Peace and American Academy of Arts and Sciences

[25] Smith, A. (1978). Lectures on Jurisprudence. Oxford: Oxford University Press

[26] Transparency International (2007). Global Corruption Report 2007: Corruption in Judicial Systems. New York: Cambridge University Press.

[27] Transparency International (2011). Global Corruption Barometer 2010/2011. Available at http//gcb.transparency.org/gcb2010/11/results/.

[28] Transparency International (2012). Transparency International Annual Report $2011 . \quad$ Available at: www.transparency.org.

[29] Uslaner, E. M. (2008). Corruption, Inequality, and the Rule of Law: The Bulging Pocket Makes the Easy Life. New York: Cambridge University Press. 